\section{Genetic parameters and gain from selection in sweet potato genotypes with high beta- carotene content}

\author{
Maria Eduarda Facioli Otoboni ${ }^{{ }^{*}}$, Darllan Junior Luiz Santos \\ Ferreira de Oliveira ${ }^{2}$, Pablo Forlan Vargas ${ }^{3}$, Bruno Ettore Pavan ${ }^{1}$ \\ and Maria Isabel Andrade ${ }^{4}$
}

\begin{abstract}
Estimating genetic parameters is an essential procedure to define strategies for breeding and selection of higher yielding genotypes. The use of a selection index can assist in decision making by combining the high yield trait with other desirable traits. The objective of this study was to verify the possibility of gains from selection in a sweet potato population to select potentially promising genotypes. The experiment was conducted in a randomized block design, with three plants per plot and two replications, consisting of 255 sweet potato genotypes and a commercial cultivar (256 treatments). The data were analyzed through REML/BLUP. Genetic gains were evaluated using selection indexes based on the rank sun. The plant population tested showed high genetic variability; $81.25 \%$ of the traits had genotypic coefficients of variation above $20 \%$, which indicates conditions favorable to selection with considerable genetic advances. CERAT31-01, CERAT21-02, and CERAT51-30 can be recommended as the most promising genotypes.
\end{abstract}

Keywords: Ipomoea batata, genetic variability, provitamin A.

\section{INTRODUCTION}

Sweet potato (Ipomoea batata) is a tuberous vegetable grown throughout Brazil due to its hardiness, easy management, low production cost, and wide range of use. Its root tubers are consumed and are the main commercial part of this plant. Sweet potato has high yield potential and wide phenotypic and genotypic variability, but the average yield in Brazil is low: approximately $12 \mathrm{Mg}$ ha $^{-1}$ (Oliveira et al. 2017). This is because most sweet potato crops are grown from local non-selected varieties and use a low level of technology, which results in yields below crop potential. With new market opportunities for this crop, research aims to obtain new genetic materials to add value to the product and encourage consumption based on the versatility of this food (EMBRAPA 2017). Current expectations are that Brazilian sweet potato breeding programs will achieve development of new cultivars that meet the demands of farmers for increased yield and that result in sustainable development of sweet potato production in Brazil (EMBRAPA 2016).

Sweet potato has considerable socioeconomic importance as a result of the high nutritional value of its roots. It is a significant source of carbohydrates, vitamins, and minerals, which makes it a food that can ensure the food security
Crop Breeding and Applied Biotechnology 20(3): e31632038, 2020 Brazilian Society of Plant Breeding. Printed in Brazil http://dx.doi.org/10.1590/198470332020v20n3a42

\section{*Corresponding author: E-mail: eduarda_ottoboni@hotmail.com (D) ORCID: 0000-0002-7288-0508}

Received: 08 April 2020

Accepted: 07 June 2020 Published: 21 August 2020

\footnotetext{
${ }^{1}$ Universidade Estadual Paulista, Departamento de Fitotecnia, Tecnologia de Alimentos e Sócio Economia, Rua Monção, Zona Norte, 15.385-000, Ilha Solteira, SP, Brazil

2 Universidade Estadual Paulista, Via de Acesso Professor Paulo Donato Castelane Castellane, Vila Industrial, 14.884-900, Jaboticabal, SP, Brazil

${ }^{3}$ Universidade Estadual Paulista, Avenida Nelson Brihi Badur, Vila Tupy, 11.900-000, Registro, SP, Brazil

${ }^{4}$ International Potato Center, Avenida FPLM, Maputo, Mozambique
} 
of a population (Vargas et al. 2017). In addition, the orange-fleshed cultivars are rich in carotenoids, mainly beta-carotene. Beta-carotene has provitamin A and antioxidant activity. Vitamin A deficiency is a public health problem in Brazil, mainly in the North, Northeast, and Southeast regions (Milagres et al. 2007), and the consumption of orange-fleshed sweet potato is a good alternative for reducing deficiency of this vitamin. Dietary requirements of vitamin A depend on age, sex, and lifestyle. The recommended daily allowance of vitamin A for healthy men from 10 years of age on is $600 \mu \mathrm{g}$ RAE (Retinol Activity Equivalent) day ${ }^{-1}$. For pregnant women this value is $800 \mu \mathrm{g} \mathrm{RAE} \mathrm{day}{ }^{-1}$, and for lactating women the values are $850 \mu \mathrm{g}$ RAE day $^{-1}$ (Burri 2011). The consumption of 100 grams of orange-fleshed sweet potato daily is estimated as sufficient to satisfy the necessary daily requirement of vitamin A (Roca and Manrique 2005).

Thus, selecting sweet potato cultivars with high levels of beta-carotene, adapted to local environmental conditions, and with good yields can assist in developing cultivars to supply human nutritional requirements, especially for low-income populations. Estimates of genetic parameters and the use of a selection index are promising strategies for selection of genotypes, since they provide guidelines for the selection process. Estimates of genetic parameters are essential for choosing methods for selection; they allow inferences of predicted gains from selection (Azevedo et al. 2015) and guide different selection strategies that allow breeders to make most efficient use of these parameters.

Success in plant breeding depends on the existence of genetic variability for selection of superior genotypes; the selected individuals must have favorable attributes (Leite et al. 2016) that result in better performance and meet market demands. Correct classification of genotypes must consider several traits simultaneously (Krause et al. 2012). The use of selection indexes is an alternative for selection through estimation of percentage gains in plant breeding programs. Thus, the objective of this study was to verify the presence of genetic variability and the possibility of gains from selection in a sweet potato population with high beta-carotene content to select potentially promising genotypes.

\section{MATERIAL AND METHODS}

The experiment was conducted under field conditions in the experimental area of the Teaching, Research, and Extension Farm of the FEIS/UNESP, Ilha Solteira campus, in Selvíria, MS, Brazil (lat 20 20’39.40” S, long 51 23" 51.00" $\mathrm{W}$, alt $335 \mathrm{~m}$ asl). The soil of the experimental area was classified as a Latossolo Vermelho Distroférrico (Typic Hapludox) of clayey texture (EMBRAPA 2013). Conventional tillage was used in the area, and 40-cm height seed beds were prepared, spaced at $1.20 \mathrm{~m}$. The soil was fertilized together with tillage by incorporating $500 \mathrm{~kg} \mathrm{ha}^{-1}$ of a 04-14-08 NPK fertilizer, supplemented with $133 \mathrm{~kg} \mathrm{ha}^{-1}$ of potassium chloride and $166 \mathrm{~kg} \mathrm{ha}^{-1}$ of single superphosphate.

The sweet potato genotypes used were from an elite population developed by the breeding program of the International Potato Center (CIP) and the Agricultural Research Institute of Mozambique (IIAM). Fifteen families of half-sib progenies obtained through open pollination (polycrosses) were evaluated. Each family was represented by 17 progenies, which were cloned, resulting in a clonal treatment, for a total of 255 new treatments. A control treatment was also used, consisting of an orange-fleshed commercial cultivar (Beauregard) that exhibited good yield (Cecílio Filho et al. 2016), thus resulting in a clonal test of 256 treatments.

Before implementation of the experiment, the sweet potato seeds were chemically scarified with sulfuric acid and placed in 162-cell polystyrene trays filled with commercial substrate for germination. The seedlings were transplanted to $5-L$ pots filled with a composting material for propagation.

On January 17,2019 , stems with a length of approximately $30 \mathrm{~cm}$ and 8 to 10 nodes were chosen to set up the experiment in a randomized block design with two replications. Plots consisted of 1-m rows with spacing of $1 \mathrm{~m}$ between rows and $0.33 \mathrm{~m}$ between plants, constituting a total area of $520 \mathrm{~m}^{2}$. Fertilization was side-dressed at 30 days after planting (DAP), using $30 \mathrm{~kg} \mathrm{ha}^{-1}$ of $\mathrm{N}$. Weeds were controlled manually in the plant rows, and chemical control with a Linuron-based product $\left(0.6 \mathrm{~L} \mathrm{ha}^{-1}\right)$ and a Clethodim + Alkylbenzene-based product $\left(0.20 \mathrm{~L} \mathrm{ha}^{-1}\right)$ was used between the plant rows. A central pivot irrigation system was used throughout the crop cycle, applying a 12-mm water depth every three days.

The plants were harvested at 127 DAP to evaluate the following quantitative traits: total root yield (TRY) - total root weight of plants harvested in the plot, converted to $\mathrm{Mg} \mathrm{ha}^{-1}$; commercial root yield (CRY) - roots with weights greater than $80 \mathrm{~g}$ in the plot, converted to $\mathrm{Mg} \mathrm{ha}^{-1}$; non-commercial root yield (NCRY) - roots with weights of less than $80 \mathrm{~g}$ 
in the plot, converted to $\mathrm{Mg} \mathrm{ha}^{-1}$; percentage of commercial root yield $(\% \mathrm{CRY})$ - obtained by [(CRY / TRY) $\left.\times 100\right]$; total number of roots (TNR) - number of roots per plant harvested in the plot, converted to roots ha-1; number of commercial roots (NCR) - number of roots per plant harvested in the plot with weights above $80 \mathrm{~g}$, converted to roots ha-1; number of non-commercial roots (NNCR) - number of roots per plant harvested in the plot, with weights below $80 \mathrm{~g}$, converted to roots ha-1; mean root weight (MRW) - obtained by TRY / TNR; mean commercial root weight (MCRW) - obtained by CRY / NCR; total root dry weight (TRDW) - root samples were oven dried at $65^{\circ} \mathrm{C}$ for 72 hours until constant weight to determine their dry weight (\%), which was converted to $\mathrm{Mg} \mathrm{ha}^{-1}$; and root dry matter content (RDMC) - obtained by $[($ TRDW $\times 100) /$ fresh weight $]$.

Root quality traits were visually evaluated using a scoring scale from 1 to 5 , where 1 corresponds to the least attractive roots and 5 to the most attractive ones. The scores were attributed to the traits considering sweet potato peel color $(P C)$, flesh color ( $F C)$, root damage (RD), root shape (RSh), and root size (RSi). The final scores were the mean of the scores attributed by two evaluators.

Analyses were performed with the Selegen REML/BLUP software (Resende 2016) using model 20 (randomized blocks, unrelated clone test, one observation per plot), given by $y=X r+Z g+e$, where $y$ is the vector of the known data observed; $r$ is the vector of repeating effects (fixed effects); $g$ is the vector of genotype effects (random effects); $e$ is the vector of errors or residuals (random); and $X$ and $Z$ are the incidence matrices for these effects. The unrelated clone test (model 20) was chosen because preliminary analysis identified that the variation between families was lower than the variation within a family. This greater variation within a family than between families is because the sweet potato is a self-incompatible hexaploid species with multiple allelism for several loci, which provides considerable genetic variability. Genetic parameters and variance components were estimated. The genetic parameters and variance components included genetic variance $\sigma_{q}^{2}$; experimental error variance $\sigma_{e}^{2}$; the residual coefficient of variation $\mathrm{CV}_{g}$; the genotypic coefficient of variation $\left(C V_{g}\right)$; broad sense heritability, based on the mean of clones $h_{m c}^{2}$; the relative coefficient of variation $C V_{r}$; the overall mean; gain from selection (GS); and gain from selection - percentage (GS\%), given by GS\% = GS/MeanGain* 100.

Deviance analysis was performed to check for significance in the evaluated traits. A selective pressure of $11.72 \%$ was adopted, for a total of 30 genotypes; the direct gains for the studied traits were calculated and, subsequently, the selection index was obtained from the sum of ranks (ranks) of Mulamba and Mock (1978), based on genotypic values. This index has proven efficiency in diverse crops, such as potato (Terres et al. 2015), alfalfa (Vasconcelos et al. 2010), popcorn (Vieira et al. 2017), macaúba palm (Costa et al. 2018), yellow passion fruit (Krause et al. 2012), and coffee (Carias et al. 2016). It has proven to be reliable and has provided balanced cultivars.

This index orders genotypes according to the desired trait, and then the sum of ranks is performed, based on the multiple traits evaluated. Economic weights of 3, 1.5, 2, and 2 were adopted for CRY, \%CRY, RDMC, and FC, respectively, which are the traits of greatest agronomic and economic importance. Weights were adopted after several attempts to favor gains in desirable traits (CRY, \%CRY, RDMC, and FC). These higher weights were used to favor gain in these traits, selecting the genotypes that show superiority in these traits for the next evaluation and selection cycle. A weight of 1 was adopted for the other traits.

The CRY trait is the most important trait, considering that increasing commercial yield is essential. This also explains the choice of trait \%CRY. The RDMC was chosen because of the consumer preference factor; selection in the present study was based on fresh consumption, and Brazilian consumers prefer larger sweet potatoes; thus, higher dry weights are desirable for selection. FC is the most important trait related to root quality because it indicates the presence of beta-carotene, which is the main trait evaluated in the present study. Weight 1 was adopted for all the other traits. Several weights were tested to choose those to be used, trying to promote gains in all the traits to maximize them and make the index as balanced as possible.

Regarding gain from selection for traits related to quality of the roots, the values were rounded off, without decimal values, to follow the evaluation pattern. Values of 0.51 or more were rounded up, and values less than or equal to 0.50 were rounded down.

\section{RESULTS AND DISCUSSION}


The genotypic coefficients of variation $\left(\mathrm{CV}_{\mathrm{g}}\right)$ showed genetic variability among the 255 genotypes for most of the 16 traits evaluated (Table 1): $81.25 \%$ of the traits had $\mathrm{CV}_{\mathrm{g}}$ above $20 \% ; 12.5 \%$ had $\mathrm{CV}_{\mathrm{g}}$ from $10 \%$ to $20 \%$; and $6.25 \%$ had $\mathrm{CV}_{\mathrm{g}}$ below $10 \%$. All traits showed significance at $1 \%$ probability by the chi-square test at 1 degree of freedom. The estimates of $\mathrm{CV}_{\mathrm{g}}$ for yield traits were higher than those of the residual coefficient of variation, except for percentage of commercial root yield (\%CRY) and root dry matter content (RDMC), showing a favorable situation for selection. Regarding the traits related to root quality ( $P C, F C, R D, R S h$, and $R S i)$, the $\mathrm{CV}_{\mathrm{g}}$ was higher than the $\mathrm{CV}_{\mathrm{e}}$ only for flesh color (FC), which is the most important quality trait because it indicates the presence or absence of beta-carotene, the main trait evaluated in the present study.

The residual coefficient of variation $\left(\mathrm{CV}_{\mathrm{e}}\right)$ is the parameter that indicates the magnitude of experimental precision (Pimentel-Gomes and Garcia 2002). Although $\mathrm{CV}_{\mathrm{e}}$ values were high, estimates of heritability $\left(\mathrm{h}^{2}\right)$ and relative coefficient of variation $\left(\mathrm{CV}_{\mathrm{r}}\right.$ ) were promising (Table 1). These parameters measure the degree of genetic determination of a trait, predicting that the genotypes evaluated have high genetic variability, even with significant environmental effect on the traits analyzed. Genetic variability is essential for the establishment of a breeding program, but efficient selection of superior genotypes depends on the genetic and environmental parameters related to the traits of interest (Blind et al. 2018).

The genetic variation found was positive for the estimates of heritability. The estimated values showed high variation, from 0.42 to 0.88 (Table 1), indicating the possibility of successful selection. The highest heritabilities found were for total root yield (TRY; 0.88), commercial root yield (CRY; 0.88), mean commercial root weight (MCRW; 0.86), and FC (0.86). Among the traits evaluated, $56.25 \%$ had heritability above 0.80 , and $31.25 \%$ had heritability from 0.50 to 0.79 . High heritability is essential for successful selection, allowing the breeder to use the most appropriate selection strategies. The results found for the most important traits (CRY, \%CRY, RDMC, and FC) show an excellent perspective for the genotype selection process based on them. Heritability in sweet potato is important because dominance and epistasis effects are maintained by vegetative propagation (Gonçalves Neto et al. 2012). Vegetative propagation is the most efficient propagation system for sweet potato; thus, these effects are focused on the varieties selected for commercial growing (Azevedo et al. 2015).

The success of selection was confirmed by attaining $\mathrm{CV}_{\mathrm{r}}$ values close to or greater than 1 for all traits under evaluation, ranging from 0.61 (RD) to 1.94 (TRY) (Table 1), which indicates the possibility of more genetic gains. According to Vencovsky and Barriga (1992), when the $\mathrm{CV}_{r}$ is greater than or equal to 1 , genetic variation is the factor most responsible for the estimated variation in the experimental data, and this parameter can be used as an index, indicating the degree of ease in selection of genotypes for each trait. Carmona et al. (2015) evaluated the genetic divergence among 23 accessions of sweet potato in Brasília, DF, Brazil, and found lower CV for TRY (0.93) and CRY (1.05) compared to the values found

Table 1. Estimates of genetic parameters for agronomic and economic traits of sweet potato

\begin{tabular}{|c|c|c|c|c|c|c|c|c|c|c|c|c|c|c|c|c|}
\hline \multirow{3}{*}{$\begin{array}{l}\text { Esti- } \\
\text { mates } \\
\sigma_{g}^{2}\end{array}$} & \multicolumn{14}{|c|}{ Variable } & \multirow[b]{2}{*}{ RSh } & \multirow[b]{2}{*}{ RSi } \\
\hline & TRY & CRY & NCRY & \%CRY & MRW & MCRW & TNR & NCR & NNCR & RDMC & TRDW & PC & FC & RD & & \\
\hline & $161.83^{* *}$ & $139.62^{* *}$ & $6.77^{* *}$ & $248.61^{* *}$ & $0.01^{* *}$ & $0.03^{* *}$ & $5563.79^{* *}$ & $1261.47^{* *}$ & $2555.73^{* *}$ & $6.67^{* *}$ & $14323194.77^{* *}$ & ${ }^{*} 0.39^{* *}$ & $1.24^{* *}$ & $0.19^{* *}$ & $0.33^{* *}$ & $0.47^{* *}$ \\
\hline$\sigma_{f}^{2}$ & 204.68 & 177.13 & 12.07 & 570.19 & 0.02 & 0.0504 & 627.25 & 1749.67 & 4244.56 & 23.14 & 18279198.21 & 1.01 & 1.63 & 0.72 & 0.79 & 0.98 \\
\hline$h_{m c}^{2}$ & 0.88 & 0.88 & 0.71 & 0.60 & 0.81 & 0.86 & 0.84 & 0.83 & 0.75 & 0.44 & 0.87 & 0.55 & 0.86 & 0.42 & 0.59 & 0.65 \\
\hline$C V_{g}(\%)$ & 58.19 & 65.38 & 68.81 & 20.44 & 68.72 & 64.50 & 55.13 & 56.40 & 69.95 & 8.69 & 58.95 & 22.02 & 39.97 & 14.42 & 19.14 & 21.96 \\
\hline$C V_{r}(\%)$ & 1.94 & 1.92 & 1.13 & 0.87 & 1.48 & 1.77 & 1.64 & 1.60 & 1.23 & 0.63 & 1.90 & 0.79 & 1.77 & 0.61 & 0.85 & 0.96 \\
\hline GS & 24.33 & 22.26 & 4.48 & 12.86 & 0.250 & 0.378 & 135.078 & 64.425 & 90.887 & 3.05 & 7.22 & 0.83 & 1.77 & 0.43 & 0.67 & 0.80 \\
\hline GS\% & 111.35 & 123.18 & 118.51 & 16.67 & 126.08 & 126.00 & 99.85 & 102.35 & 125.76 & 10.27 & 112.61 & 29.12 & 63.44 & 14.00 & 22.11 & 25.55 \\
\hline Mean & 21.85 & 18.07 & 3.78 & 77.10 & 0.19 & 0.30 & 135.278 & 62.968 & 72.268 & 29.72 & 6.42 & 2.85 & 2.79 & 3.07 & 3.03 & 3.13 \\
\hline
\end{tabular}

TRY: total root yield ( $\left.\mathrm{Mg} \mathrm{ha}^{-1}\right)$; CRY: commercial root yield ( $\left.\mathrm{Mg} \mathrm{ha}^{-1}\right)$ NCRY: non-commercial root yield (Mg ha-1); \%CRY: percentage of commercial root yield; MRW: mean root weight (kg); MCRW: mean commercial root weight (kg); TNR: total number of roots (ha $\left.{ }^{-1}\right)$; NCR: number of commercial roots (ha $\left.{ }^{-1}\right)$; NNCR: number of non-commercial roots (ha-1); RDMC: root dry matter content (\%); TRDW: total root dry weight (Mg ha-1); PC: peel color; FC: flesh color; RD: root damage; RSh: root shape, RSi: root size; $\sigma_{g}^{2}$ : genotypic variance; $\sigma_{e}^{2}$ : residual variance; $\sigma_{f}^{2}$ : phenotypic variance; $h^{2}$ mc: mean heritability of the clones; $C V_{g}(\%)$ : genotypic coefficient of variation; $C V_{e}(\%)$ : residual coefficient of variation; $C V_{r}(\%)=\frac{C V_{g}}{C V}$ : ratio between genotypic coefficient of variation and environmental coefficient of variation; GS: gain from selection; GS\%: gain from selection gain (percentage) by index based on direct selection. ${ }^{* *}$ Significant at $1 \%$ in the chi-square test. 
Genetic parameters and gain from selection in sweet potato genotypes with high beta-carotene content

in the present study (Table 1). The same occurred for the heritability estimates and genotypic coefficients of variation. Azevedo et al. (2015) evaluated the agronomic performance and genetic parameters of 65 sweet potato genotypes in Diamantina, MG, Brazil, and found $\mathrm{CV}_{\mathrm{g}}$ of $31.14 \%$ (TRY) and $45.53 \%$ (CRY), and heritability of 0.71 (TRY) and 0.78 (CRY), estimates which were lower than those found in the present study.

Little improved species, such as sweet potato, tend to express high genetic variability. This provides a significant number of genotypes to be evaluated and increases the potential for breeding programs to obtain new commercial cultivars through genetic improvement.

Estimates of direct selection had significant predicted gains, ranging from $10.27 \%$ to $126.08 \%$, indicating a favorable condition for selection (Table 1). However, to develop a cultivar, a genotype must have several favorable attributes simultaneously because selection based on only one trait can result in unsatisfactory performance in other traits. Therefore, selection based on selection indexes was a reliable strategy for obtaining balanced gains for all traits evaluated, maximizing simultaneous gains for the genetic parameters.

The 30 best genotypes were selected through the index based on the sum of ranks. The index provided considerable gains from selection, except for root dry matter content (RDMC) (Table 2). The low gain (7.67\%) found for non-commercial root yield (NCRY) is favorable for selection because inverse selection was performed for this trait, searching for the genotypes with the lowest values. The same procedure was adopted for number of non-commercial roots, which resulted in negative gain $(-3.71 \%)$, i.e., a reduction in the number of non-commercial roots. The negative gain in RDMC (-2.95\%), though it constitutes a main trait, indicates that the genotypes selected tend to show a reduction in this trait for the next selection cycle. However, as this negative gain was low, this reduction will not be substantial. Furthermore, increases in gains for CRY, maximizing the weight attributed to this trait, negatively affected the RDMC gains - the index weighs the gains by considering all traits evaluated. In addition, the environmental effect was greater than the genetic effect on this trait (Table 1). Rodrigues and Pereira (2003) evaluated inter- and intragenerational correlations and heritability of color, dry matter, and yield of 250 potato (Solanum tuberosum) clones in Pelotas, RS, Brazil. They reported that the selection of superior genotypes based on dry matter content should be made only after the third generation because first-generation selection has little effect on plant yields and often exhibits little genetic control of this trait. In the present study, RDMC was the trait with the second lowest heritability and the lowest expected gain.

The gains with the selection index ranged from $-3.71 \%$ to $75.27 \%$ (Table 2). The results presented in Table 2 show the expected mean (M1) of the selected population, including the genetic gains obtained. The index gain for TRY was 16.56 $\mathrm{Mg} \mathrm{ha}^{-1}$, representing $69.81 \%$ efficiency of the index compared to direct gain, with a selection differential of $35.32 \mathrm{Mg}$ $\mathrm{ha}^{-1}$, i.e., the mean of the improved population (M1) will be $35 \mathrm{Mg} \mathrm{ha}^{-1}$ higher than the mean of the original population. CERAT31-01 was the highest yielding genotype among those selected, with TRY of $92.73 \mathrm{Mg} \mathrm{ha}^{-1}$, which is $434.5 \%$ higher than that of the control (21.34 Mg ha-1); CERAT16-20 was the second highest yielding genotype (88.56 Mg ha-1). Santos Neto et al. (2017) evaluated the yield of three sweet potato clones in São Cristóvão, SE, Brazil, and found a mean total root yield of $41.78 \mathrm{Mg} \mathrm{ha}^{-1}$, which was $15.39 \mathrm{Mg} \mathrm{ha}^{-1}$ less than that found in the present study (a mean of $57.17 \mathrm{Mg} \mathrm{ha}^{-1}$ for the 30 genotypes selected).

CRY showed the highest gain (75.27\%). CERAT31-01 and CERAT16-20 were once more superior to the others, at 88.20 and $87.17 \mathrm{Mg} \mathrm{ha}^{-1}$, respectively. The selected genotypes were much superior to the control, which had a CRY of 15.31 $\mathrm{Mg} \mathrm{ha}^{-1}$. Andrade Júnior et al. (2018) evaluated the quantitative and qualitative potential of 40 sweet potato genotypes in Diamantina, MG, Brazil; the highest TRY values they found were $47.1 \mathrm{Mg} \mathrm{ha}^{-1}$, and the highest CRY values were 36.7 $\mathrm{Mg} \mathrm{ha}{ }^{-1}$, significantly lower than the values found in the present study. Silva et al. (2015) evaluated the performance of six sweet potato cultivars in Canoinhas, SC, Brazil, and found lower results for CRY over two years of study, with means of $21.21 \mathrm{Mg} \mathrm{ha}^{-1}$ in 2012 and $23.66 \mathrm{Mg} \mathrm{ha}^{-1}$ in 2013. Amaro et al. (2019) evaluated the performance of the cultivars Beauregard, Brazlândia Branca, Brazlândia Rosada, Brazlândia Roxa, BRS Amelia, BRS Cuia, BRS Rubissol, and Princesa in Umbaúba, SE, Brazil, and found lower results, with a mean CRY of $29.70 \mathrm{Mg} \mathrm{ha}^{-1}$.

Although the selection of sweet potato genotypes is mainly based on commercial root production, total root yield is also important, since roots with weight insufficient for commercial sale can be used for other purposes, such as in the food industry, for animal feed, and for ethanol production. However, in the search for genotypes with the lowest values for NCRY, CERAT52-09 was the most promising, with 100\% commercial roots. CERAT51-30 had the highest NCRY 
Table 2. Expected mean (M1) of the thirty best sweet potato genotypes selected through the index based on the sum of ranks and predicted genetic gains from selection (GS)

\begin{tabular}{|c|c|c|c|c|c|c|c|c|c|c|c|c|c|c|c|c|}
\hline \multicolumn{17}{|c|}{ Variable } \\
\hline & TRY & CRY & NCRY & $\%$ CRY & MRW(Kg) & MCRW(Kg) & TNR & NCR & NNCR & RDMC & TRDW & PC & FC & RD & RSh & RSi \\
\hline SD & 35.32 & 35.76 & -0.25 & 20.48 & 0.215 & 0.225 & 43.091 & 40.782 & 2.351 & -0.29 & 10.15 & 0.15 & 1.21 & 0.93 & 0.97 & 0.87 \\
\hline GS & 16.56 & 16.75 & -0.18 & 8.81 & 0.093 & 0.103 & 36.32 & 34.14 & 1.77 & -0.09 & 4.74 & 0.22 & 0.55 & 0.20 & 0.39 & 0.43 \\
\hline GS\% & 69.81 & 75.27 & 7.67 & 68.50 & 37.21 & 27.76 & 26.89 & 53.00 & -3.71 & -2.95 & 65.69 & 26.49 & 31.31 & 46.89 & 57.64 & 53.94 \\
\hline CERAT21-21 & 55.37 & 54.69 & 0.87 & 100.00 & 0.394 & 0.450 & 130.750 & 109.455 & 21.295 & 30.11 & 16.48 & 3 & 5 & 4 & 4 & 4 \\
\hline CERAT16-03 & 62.10 & 58.40 & 3.90 & 100.00 & 0.448 & 0.558 & 129.623 & 92.621 & 37.002 & 34.40 & 20.48 & 4 & 5 & 4 & 4 & 4 \\
\hline CERAT24-04 & 52.86 & 50.88 & 2.17 & 100.00 & 0.347 & 0.684 & 142.623 & 59.702 & 82.921 & 28.41 & 14.89 & 4 & 5 & 4 & 4 & 4 \\
\hline CERAT16-04 & 62.14 & 59.61 & 2.73 & 100.00 & 0.486 & 0.588 & 116.121 & 92.621 & 23.500 & 26.99 & 17.02 & 3 & 5 & 3 & 4 & 4 \\
\hline CERAT21-02 & 79.18 & 79.28 & 0.10 & 100.00 & 0.769 & 0.782 & 92.623 & 92.111 & 512 & 27.79 & 22.21 & 3 & 4 & 3 & 4 & 4 \\
\hline CERAT21-04 & 43.00 & 41.05 & 2.15 & 100.00 & 0.287 & 0.346 & 137.623 & 99.745 & 37.878 & 31.27 & 13.02 & 4 & 5 & 4 & 4 & 4 \\
\hline CERAT52-25 & 42.22 & 42.06 & 0.35 & 100.00 & 1.676 & 1.692 & 16.246 & 15.957 & 289 & 31.62 & 12.89 & 3 & 3 & 4 & 5 & 5 \\
\hline CERAT31-06 & 56.89 & 53.98 & 3.10 & 100.00 & 0.281 & 81 & & 142.621 & 80.465 & 30.39 & 17.07 & 2 & 3 & 4 & 4 & 4 \\
\hline CERAT52-22 & 62.81 & 60.48 & 2.52 & 100.00 & 0.297 & 0.362 & 226.291 & 168.413 & 57.878 & 29.52 & 18.22 & 3 & 2 & 4 & 4 & 4 \\
\hline CERAT34-18 & 64.74 & 58.15 & 6.79 & 95.52 & 0.285 & 0.377 & 244.129 & 147.332 & 96.797 & 30.15 & 19.12 & 4 & 4 & 4 & 4 & 4 \\
\hline CERAT16-20 & 88.56 & 87.17 & 1.58 & 100.00 & 0.587 & 0.705 & 146.042 & 116.872 & 29.170 & 26.67 & 24.01 & 2 & 2 & 4 & 3 & 4 \\
\hline CERAT31-01 & 92.73 & 88.20 & 4.73 & 100.00 & 0.369 & 0.486 & 277.797 & 185.208 & 92.589 & 27.53 & 25.90 & 3 & 3 & 3 & 4 & 4 \\
\hline CERAT25-24 & 48.22 & 46.13 & 2.29 & 100.00 & 0.359 & 0.433 & 126.291 & 88.413 & 37.878 & 31.23 & 14.66 & 3 & 4 & 4 & 3 & 2 \\
\hline CERAT31-09 & 57.54 & 54.52 & 3.21 & 100.00 & 0.366 & 0.599 & 151.542 & 75.787 & 75.755 & 27.85 & 16.14 & 4 & 3 & 4 & 4 & 4 \\
\hline CERAT25-11 & 47.64 & 46.74 & 1.10 & 100.00 & 0.342 & 0.464 & 124.924 & 82.894 & 42.030 & 30.25 & 14.17 & 2 & 3 & 3 & 4 & 3 \\
\hline CERAT56-23 & 55.35 & 51.32 & 4.23 & 98.21 & 0.369 & 0.516 & 147.334 & 84.204 & 63.129 & 29.43 & 16.17 & 4 & 5 & 4 & 4 & 4 \\
\hline CERAT24-25 & 60.39 & 49.71 & 10.87 & 84.99 & 0.232 & 0.394 & 319.882 & 113.664 & 206.218 & 31.42 & 18.70 & 3 & 4 & 4 & 4 & 4 \\
\hline CERAT52-09 & 36.27 & 36.46 & 0.00 & 100.00 & 0.578 & 0.587 & 40.287 & 40.285 & 2 & 33.94 & 11.39 & 3 & 4 & 4 & 3 & 3 \\
\hline Mean & 57.17 & 53.83 & 3.53 & 97.58 & 0.405 & 0.525 & 178.369 & 103.750 & 74.619 & 29.43 & 16.57 & 3 & 4 & 4 & 4 & 4 \\
\hline Beauregard & 21.34 & 15.31 & 6.02 & 69.16 & 0.120 & 0.200 & 187.077 & 77.296 & 109780 & 24.68 & 5.46 & 3 & 4 & 3 & 3 & 4 \\
\hline
\end{tabular}

TRY: total root yield ( $\left.\mathrm{Mg} \mathrm{ha}^{-1}\right)$; CRY: commercial root yield (Mg ha-1) NCRY: non-commercial root yield (Mg ha $\left.{ }^{-1}\right)$; \%CRY: percentage of commercial root yield; $\mathrm{MRW}^{-}$mean root weight (kg); MCRW: mean commercial root weight (kg); TNR: total number of roots (ha-1); NCR: number of commercial roots (ha-1); NNCR: number of non-commercial roots (ha-1); RDMC: root dry matter content (\%); TRDW: total root dry weight (Mg ha-1); PC: peel color; FC: flesh color; RD: root damage; RSh: root shape, RSi: root size; SD: selection differential; GS: gain from selection gain; GS\%: gain from selection (percentage) by index based on direct selection.

(13.83 Mg ha-1). The gain for NCRY was $7.67 \%$, which is favorable for selection, because the lower the non-commercial root production, the higher the percentage of commercial root production.

The gain for percentage of commercial root yield (\%CRY) was $68.50 \% ; 21$ out of the 30 genotypes selected had $100 \%$ commercial roots, with a mean of $97.58 \%$. Amaro et al. (2019) found a mean \%CRY of $81.52 \%$, with results ranging from $72.44 \%$ to $88.97 \%$.

The mean root weight (MRW) accounts for both commercial (above $80 \mathrm{~g}$ ) and non-commercial roots. The gain for this trait through the index was $37.21 \%$, representing a gain of $0.093 \mathrm{~kg}$. The highest MRW found by the index was for the genotype CERAT52-25, with a MRW of $1.676 \mathrm{~kg}$ per root. This high MRW found for CERAT52-25 is not common; 
however, this was due to its low number of roots $(16,246$ roots; total root weight of $42.22 \mathrm{Mg} \mathrm{ha-1})$ compared to the other genotypes, which indicates that most of its roots are commercial. This can be shown by the NCRY, which was $0.35 \mathrm{Mg} \mathrm{ha}{ }^{-1}$, the third lowest among the selected populations. The second highest MRW $(0.764 \mathrm{~kg})$ was found for the genotype CERAT21-02, followed by CERAT16-20 (mean of $0.587 \mathrm{~kg}$ per root). These results were higher than those found by Azevedo et al. (2015), for whom the highest MRW was $0.205 \mathrm{~kg}$.

The CERAT52-25 genotype had the highest mean commercial root weight (MCRW), $1.692 \mathrm{~kg}$, for the same reasons indicated for MRW. When selecting genotypes for fresh consumption, the MCRW should not exceed $0.500 \mathrm{~kg}$. Thus, CERAT31-01 $(0.486 \mathrm{~kg})$ and CERAT31-22 $(0.485 \mathrm{~kg})$ were the most promising genotypes. The lowest MCRW was found for CERAT52-23 $(0.287 \mathrm{~kg})$. The mean MCRW was $0.525 \mathrm{~kg}$. The MCRW of all the genotypes was superior to that of the control $(0.200 \mathrm{~kg}$ ). Amaro et al. (2019) found lower results of MCRW (mean of $0.180 \mathrm{~kg}$ ); the commercial cultivar Beauregard had MCRW of $0.182 \mathrm{~kg}$. Amaro et al. (2017) found mean MCRW of $0.299 \mathrm{~kg}$ and $0.273 \mathrm{~kg}$ for Beauregard. The highest MCRW found by Azevedo et al. (2015) was $0.253 \mathrm{~kg}$.

The gain for total number of roots (TNR) was $26.89 \%$, and the gain for number of commercial roots (NCR) was $53 \%$. The number of non-commercial roots (NNCR) had a negative gain of $-3.71 \%$. CERAT25-01 showed the highest TNR $(397,295)$ but the lowest MRW $(0.162 \mathrm{~kg})$ and the second lowest MCRW $(0.300 \mathrm{~kg})$. CERAT31-01 had the highest NCR (185.208), which was $239.6 \%$ greater than that of the commercial cultivar (Beauregard) evaluated. CERAT52-09 was promising with the smallest NNCR, only 2 non-commercial roots, while the control had 109.780 non-commercial roots.

The gain from selection for root dry matter content (RDMC) was $-2.95 \%$, ranging from $34.40 \%$ (CERAT16-03) to $26.41 \%$ (CERAT21-13), with a mean of 29.43\%. According to EMBRAPA (2008), sweet potato roots have a RDMC of $30 \%$. The RDMC of the commercial cultivar (Beauregard) was $24.68 \%$ lower than that of the genotype CERAT21-13, which had the lowest RDMC among the genotypes selected. These results were superior to those found by Andrade Júnior et al. (2012), who evaluated 12 sweet potato clones in Diamantina, MG, Brazil, and found a mean RDMC of 27.30\%. However, in general, they were lower than the results of Vieira et al. (2015), who evaluated 60 clones with a focus on ethanol production in Palmas, TO, Brazil; they found RDMC of 33.05\%. RDMC is directly related to the specific density of the sweet potato roots; from the industry perspective, high dry matter content of roots is desirable because this trait leads to higher processing yields.

The gain for total root dry weight (TRDW) was 65.69\%; CERAT31-01 (25.90 Mg ha-1) and CERAT16-20 (24.01 Mg ha-1) were the most promising genotypes. CERAT52-09 had the lowest performance, with TRDW of $11.39 \mathrm{Mg} \mathrm{ha}^{-1}$. The mean of the genotypes was 16.57 Mg ha-1. Andrade Júnior et al. (2018) found lower results, with a mean TRDW of 8.92 Mg ha-1.

Genotypes with the highest scores for traits related to root quality were selected (Table 2); scores 4 and 5 indicate superior genotypes for the trait evaluated. The gain from selection for peel color (PC) was $26.49 \%$, with a mean score of 3. Only two genotypes among the 30 selected attained score 5: CERAT21-13 and CERAT35-09. Genotypes with scores 4 and 5 for flesh color (FC) indicate that they have intense orange flesh; the selection of orange-fleshed sweet potato genotypes was the focus of the present study. The selection differential for this trait was 1.21, which resulted in a gain of $31.31 \%$. Based on the visual evaluation pattern we adopted, this indicates that the genotypes selected in the present study tend to show improvements in the next selection cycle. Among the 30 genotypes selected, 14 attained score 5 for FC, and 7 genotypes had score 4, i.e., 70\% of the selected genotypes presented intense orange flesh and, consequently, high beta-carotene content. The Beauregard cultivar used as a standard had score 4 for FC.

The gain for root damage (RD) was 46.89\%; the genotypes CERAT21-13 and CERAT25-01 attained score 5. Six genotypes had score 5 for root shape (RSh). The gain for RSh (57.64\%) was higher than that of the other traits related to visual quality. Root size (RSi) exhibited gain from selection of 53.94\%, and 4 genotypes attained score 5 for that trait. The traits involving root quality are highlighted to obtain genotypes with visually appealing roots containing high beta-carotene content. CERAT51-30, CERAT21-13, and CERAT25-01 are highly promising genotypes; however, 83\% of the genotypes also showed high potential for traits of visual interest.

Considering the results from analysis of estimates of genetic parameters, the population tested in the present study showed high genetic variability, indicating favorable conditions for selection to achieve considerable genetic advances. Combined evaluation of all the traits tested shows that CERAT51-30, CERAT31-01, and CERAT21-02 can be recommended 
as the most promising sweet potato genotypes. The genotypes evaluated were significantly superior to the commercial Beauregard cultivar, and they can be placed in Value for Cultivation and Use trials. The use of these clones as cultivars will lead to considerable gains in yield. However, after recombination, even more promising and better quality genotypes are expected through the cycle 1 population and throughout the program to make use for the promising genetic base.

\section{ACKNOWLEDGMENTS}

The authors thank the São Paulo State Research Support Foundation (FAPESP) for funding this study (Proc. N. 2017 / 08032-0), the Coordination for the Improvement of Higher Education Personnel (CAPES) for granting scholarships, the Center for Tropical Roots and Starches (CERAT) of UNESP for research support, and the International Potato Center for its support.

\section{REFERENCES}

Amaro GB, Fernandes FR, Silva GO, Mello AFS and Castro LAS (2017) Desempenho de cultivares de batata doce na região do Alto Paranaíba-MG. Horticultura Brasileira 35: 286-291.

Amaro GB, Talamini V, Fernandes FR, Silva GO and Madeira NR (2019) Desempenho de cultivares de batata-doce para rendimento e qualidade de raízes em Sergipe. Revista Brasileira de Ciências Agrárias 14: e5628.

Andrade Júnior VC, Elsayed AYAM, Azevedo AM, Santos EA and Ferreira MAM (2018) Potencial quantitativo e qualitativo de genótipos de batata-doce. Revista Scientia Agraria 19: 28-35.

Andrade Júnior VC, Viana DJS, Pinto NAVD, Ribeiro KG, Pereira RC, Neiva IP, Azevedo AM and Andrade PCR (2012) Características produtivas e qualitativas de ramas e raízes de batata-doce. Horticultura Brasileira 30: 584-589.

Azevedo AM, Andrade Júnior VC, Fernandes JSC, Pedrosa CE and Oliveira CM (2015) Desempenho agronômico e parâmetros genéticos em genótipos de batata-doce. Horticultura Brasileira 33: 84-90.

Blind AD, Valente MSF, Lopes MTG and Resende MDV (2018) Estimativa de parâmetros genéticos, análise de trilha e seleção em bucha vegetal para caracteres agronômicos. Revista Brasileira de Ciências Agrárias 13: 01-08.

Burri BJ (2011) Evaluating sweet potato as an intervention food to prevent vitamin A deficiency. Comprehensive Reviews in Food Science and Food Safety 10: 118-130.

Carias CMOM, Gravina GA, Ferrão MAG, Fonseca AFA, Ferrão RG, Vivas $M$ and Viana AP (2016) Predição de ganhos genéticos via modelos mistos em progênies de café conilon. Coffee Science 11: 39-45.

Carmona PAO, Peixoto JR, Amaro GB and Mendonça MA (2015) Divergência genética entre acessos de batata-doce utilizando descritores morfoagronômicos das raízes. Horticultura Brasileira 33: $241-250$.

Cecílio Filho AB, Nascimento SMC, Silva ASN and Vargas PF (2016) Agronomic performance of sweet potato with different potassium fertilization rates. Horticicultura Brasileira 34: 588-592.

Costa AM, Motoike SY, Corrêa TR, Silva TC, Coser SM, Resende MDV and Teófilo RF (2018) Genetic parameters and selection of macaw palm
(Acrocomia aculeata) accessions: an alternative crop for biofuels. Crop Breeding and Applied Biotechnology 18: 259-266.

EMBRAPA - Empresa Brasileira de Pesquisa Agropecuária (2008) Batatadoce (Ipomoea batatas). Available at: <https://sistemasdeproducao. cnptia.embrapa.br/FontesHTML/Batata-doce/Batata-doce_ Ipomoea_batatas/composicao_uso.html>. Accessed on August 4, 2019.

EMBRAPA - Empresa Brasileira de Pesquisa Agropecuária (2013) Sistema brasileiro de classificação dos solos. Embrapa, Brasília, 353p.

EMBRAPA - Empresa Brasileira de Pesquisa Agropecuária (2016) Hortaliças em revista: Programa de melhoramento genético de batata-doce busca aumento de produtividade e qualidade das raízes. Available at: <http://ainfo.cnptia.embrapa.br/digital/bitstream/ item/176787/1/edicao201.pdf>. Accessed on May 27, 2020.

EMBRAPA - Empresa Brasileira de Pesquisa Agropecuária (2017) Melhoramento genético desenvolve batata-doce para produção de chips. Available at: <https://www.embrapa.br/busca-de-noticias/-/ noticia/20819112/melhoramento-genetico-desenvolve-batata-docepara-producao-de-chips>. Accessed on May 27, 2020.

Gonçalves Neto AC, Maluf WR, Gomes LAA, Maciel GM, Ferreira RPD and Carvalho RC (2012) Correlação entre caracteres e estimação de parâmetros populacionais para batata-doce. Horticultura Brasileira 30: 713-719.

Krause W, Souza RS, Neves LG, Carvalho MLS, Viana AP and Faleiro FG (2012) Ganho de seleção no melhoramento genético intrapopulacional do maracujazeiro-amarelo. Pesquisa Agropecuária Brasileira 47: 51-57.

Leite WS, Pavan BE, Matos Filho CHA, Alcantara Neto F, Oliveira CB and Feitosa FS (2016) Estimativas de parâmetros genéticos, correlações e índices de seleção para seis caracteres agronômicos em linhagens $\mathrm{F}_{8}$ de soja. Comunicata Scientiae 7: 302-310.

Milagres RCRM, Nunes LC and Pinheiro-Sant'ana HMA (2007) Deficiência de vitamina A em crianças no Brasil e no mundo. Revista Ciência e Saúde Coletiva 12: 1253-1266.

Mulamba NN and Mock JJ (1978) Improvement of yield potential of the Eto Blanco maize (Zea mays L.) population by breeding for plant traits. Egypt Journal of Genetics and Cytology 7: 40-51.

Oliveira LOF, Soares ER, Queiroz SF, Martínez EO, Silva MS, Nogueira AE, Ferreira ES and Vezarro AFGS (2017) Adubação e nutrição da batata- 
Genetic parameters and gain from selection in sweet potato genotypes with high beta-carotene content

doce: uma revisão. Revista Científica da Faculdade de Educação e Meio Ambiente 8: 70-90.

Pimentel-Gomes F and Garcia CH (2002) Estatística aplicada a experimentos agronômicos e florestais: exposição com exemplos e orientações para uso de aplicativos. Fundação de Estudos Agrários Luiz de Queiroz, Piracicaba, 309p.

Resende MDV (2016) Software SELEGEN - REML/BLUP: uma ferramenta útil para o melhoramento de plantas. Crop Breeding and Applied Biotechnology 16: 330-339.

Roca W and Manrique I (2005) Valorización de los recursos genéticos de raíces y tubérculos andinos para la nutrición y la salud. Agrociencia 9: 195-201.

Rodrigues AFS and Pereira AS (2003) Correlações inter e intragerações e herdabilidade de cor de chips, matéria seca e produção em batata. Pesquisa Agropecuária Brasileira 38: 599-604.

Santos Neto AR, Silva TO, Blank AF, Silva JO and Araújo Filho RN (2017) Produtividade de clones de batata doce em função de doses de nitrogênio. Horticultura Brasileira 35: 445-452.

Silva GO, Suinaga FA, Ponijaleki R and Amaro GB (2015) Desempenho de cultivares de batata-doce para caracteres relacionados com o rendimento de raiz. Revista Ceres 62: 379-383.

Terres LR, Lenz E, Castro CM and Pereira AS (2015) Estimativas de ganhos genéticos por diferentes índices de seleção em três populações híbridas de batata. Horticultura Brasileira 33: 305-310.

Vargas PF, Godoy DRZ, Almeida LCF and Castoldi R (2017) Agronomic characterization of sweet potato accessions. Comunicata Scientiae 8: $116-158$.

Vasconcelos ED, Ferreira RP, Cruz CD, Moreira A, Rassini JB and Freitas AR (2010) Estimativas de ganho genético por diferentes critérios de seleção em genótipos de alfafa. Revista Ceres 57: 205-210.

Vencovsky $R$ and Barriga $P$ (1992) Genética biométrica no fitomelhoramento. Sociedade Brasileira de Genética, Ribeirão Preto, 486p.

Vieira AD, Miranda VC, Alves, AF, Tavares AT and Momenté VG (2015) Agronomic evaluation of clones of sweet potato with potential for ethanol production. Applied Research \& Agrotechnology 8: 69-74.

Vieira RA, Rocha R, Scapim CA and Amaral Junior AT (2017) Recurrent selection of popcorn composites UEM-CO1 AND UEM-CO2 based on selection indices. Crop Breeding and Applied Biotechnology 17: $266-272$. 